the 26th the medical officer of health (having been warnor to keep his eye on her) saw hor and found a number of tiny vesicles with shotty feel on the forearms, wrists, and legs. These faded in a day or two. 'There were no symptoms. The child was not exposed to personal contact with the visitor who gave the disease to her brother, having been from home on that day. There was not any case traced to her afterwards, although she was only partially isolated. The probable explanation is that the spots were a delayed vaccination rash or a mild case of varicella. I am, Sirs, yours faithfully, Edmonton, Jan. 16th, $1905 . \quad$ H. G. JAMIsoN, M.D. R.U.I.

\section{THE TREATMENT OF HEMOPTYSIS.}

To the Editors of THE LANCET.

SIRs,-In THE LANCET of August 20th (p. 522) and Oct. 1st (p. 942), 1904, under the head of "The Medical Treatment of Deep-seated Hæmorrhage," I contributed a series of eight cases in which 13 attacks of hæmoptysis (12 phthisical and one mitral) had been, with one exception, all stopped within three minutes by inhalation of amyl nitrite. In the exception the bleeding continued in reduced amount for ten minutes. Since writing the above I have received the following from Dr. E. Leslie Pooler of South Australia: "I have tried the ampl nitrite treatment for pulmonary hæmorrhage with complete success. On the night of Sept. 27th, at 11.30 P.M., I was called for the first time to see Mr. A., aged 45 (a tubercle case), who, I was told, had been bleeding since 10 P.M. There was about a pint of blood. Inhalation stopped the hæmorrhage almost instantaneously. On Sept. 28th, 29th, 30th, and Oct. 1st there were further hæmorrhages but each ceased immediately on the inhalation. There has been no further hæmorrhage since Oct. 1st."

In THE LANCET of Nov. 19th, 1904, p. 1446, I gave $a$ priori reasons for believing that the internal administration of adrenalin would tend to exaggerate or to prolong hamoptysis. These anticipations seem fully confirmed by the experimental work of Dr. T. G. Brodie and Dr. W. E. Dixon on the "Alterations in the Systemic Circulation which tend to produce Engorgement of the Lung Capillaries," communicated to the Pathological Society of London." These investigators point out that there is no evidence that adrenalin produces any constriction of the vessels of the lung; that adrenalin produces engorgement of the lung; and further that ergot and digitalis both act similarly. Do not these facts all point to amyl nitrite inhalation as the rational treatment for hæmoptysis?

I am, Sirs, yours faithfully,

Francis EvERARD HARE, M.D.

Gower-street, W.C., Jan. 16th, 1905

\section{THE CASE OF DR. A. D. GRIFFITHS.}

\section{To the Editors of THE LANCET.}

SiRs,- - In your issue of Dec. 17th, 1904, p. 1733, under the title "A Vile Conspiracy," you published an account of an important action which was tried at the Glamorgan assizes held at Swansea last month, the plaintiff being Dr. A. D. Griffiths of Bridgend, a member of the Cardiff division of the British Medical Association and of the Cardiff Medical Society. The outstanding facts of the case will still be fresh in the minds of your readers and it will be remembered that Mr. Justice Bray pointed out that Dr. Griffiths's actions had been correct in every particular and that in concluding his summing up the judge intimated to the jury that although the damages they might award would probably never be paid they ought to give some such sum as would show that in their opinion the charges were absolutely groundless. The jury, after a brief consultation, declared a verdict for Dr. Griffiths with $£ 500$ damages, or five times as much as he had asked for.

At a meeting of the South Wales and Monmouthshire branch of the British Medical Association subsequently held at Carmarthen a motion was passed unanimously expressing the sympathy of the branch with Dr. Griffiths in his painful experience and congratulating him on the way in which he had justified its faith in his unblemished character. A similarly worded motion was also unanimously passed at a joint special meeting of the Cardifif division and of the Cardiff Medical Society on Jan. 4th and also at a meeting of the Incorporated Society of Medical Officers of Health.

1 The LanceT, Dec. 4th, 1904, p. 1784.
At the joint meeting referrer to it was made known that, as had been anticipated, none of the awarled damages will be realised by Dr. Griffiths and that his legal expenses for the action amounted to something like $£ 205$. It was strongly felt that an opportunity should be given to his fellow members of the profession and others to express their practical sympathy with Dr. Griffiths who with commendable courage and determination had successfully met so dangerous an attack not only on his own reputation but also on the bonâ fide status of the general practitioner.

A committee was accordingly appointed to establish a fund to defray the unavoidably heavy bill of costs. The committee consists of the chairmen and honorary secretaries of the Cardiff division of the British Medical Associaand of the Cardiff Medical Society respectively, Dr. R. S. Stewart and Mr. W. Randall of Bridgend, with Dr. A. P. Fiddian, 23, The Walk, Cardiff, as treasurer. Donations to the fund will be gratefully received and acknowledged by the treasurer or by the undersigned.

We are, Sirs, yours faithfully,

Thos. WALLACE, M.D. R.U.I.

Howard Lodge, Newport-road, Cardiff (Chairman, Cardiff Division, British Medical Association);

W. D. J. MorRIs, M.R.C.S. Eng. 100, Crwys-road, Cardiff (President, Cardiff Medical Society)

R. S. StewarT, M.D. Glasg.

Superintendent, Glamorgan County Asylum, Bridgend

EIVEN J MACLFAN, M.D Edin.

12, Park-place, Cardiff (Honorary Secretary

Jan. 15th, 1905. Cardiff Division, British Medical Association)

The treasurer begs to acknowledge the following donations already received or promised :-

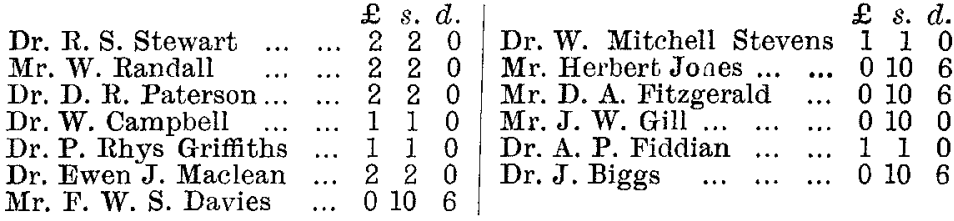

\section{PRECOCIOUS LACTATION IN MALE INFANTS. \\ To the Editors of 'THE LANCET.}

SrRs,-I think it is not yet generally recognised in the profession that the secretion of milk is natural in the newly born of both sexes. This physiological process attains its maximum between the eighth and fifteenth days after birth. That the process is a true lactation dependent upon the secretory activity of true acinous glandular structures has been proved histologically by De Sinétz, ${ }^{1}$ Variot, Kölliker, Barfurth, and others. It is to abnormal persistence or recrudescence of this physiological process that such cases as that reported by Mr. R. M. McQueen in THE LANCET of Jan. 7th, p. 25, are due. This type of precocity is more frequently seen in female than in male children and it is generally, but not invariably, accompanied by other signs of precocious sexual development. I have elsewhere cited several cases of this kind. ${ }^{2}$ In male children I have met with but very few similar examples. A typical case was, however, reported a few years ago by Rogers ${ }^{3}$ and another by Dalziel. ${ }^{4}$

I am, Sirs, yours faithfully,

Clifton, Bristol, Jan. 7th, 1905. W. RoGER WILLIams.

\section{CHLOROFORM AN ESTHESIA COMPLI- CATED BY A FIT.}

To the Editors of THE LANCET.

Sins,--I have been kindly permitted by Mr. E. Michels, senior surgeon to the German Hospital, to recount this case. A man, aged 32 years, on Dec. 3rd, 1904, fell from his bicycle while smoking, owing, he said, to a sideslip, and the pipestem was driven into his tonoue. He was not rendered unconscious. He obtained treatment but as he did not improve he came to the German Hospital on the evening of Dec. 8th

1 Recherches sur la Mamelle des Enfants Nouveau-Nés, Archives de Physiologie, 1875, p. 295.

${ }^{2}$ Diseases of the Breast, p. 83 ; also British Gynacological Journal, May, 1902.

${ }^{3}$ Brit. Med. Jour., vol. i., 1897, p. 29.

4 Glasgow Medical Journal, June, 1894 